\title{
Beach filling model to improve beach management: a case on the French Atlantic coast (Pertuis Charentais beaches)
}

\author{
V. Guyonnard \& L. Vacher \\ UMR 7266 LIttoral ENvironnement et Sociétés (LIENSS), \\ CNRS - University of La Rochelle, France
}

\begin{abstract}
The beach, a public space at the interface between land and sea, is heavily used for tourism and leisure practices, especially during the summer. This attraction generates intensive use of the space and local authorities require data to improve management of their local beaches. In this context, we have analysed beaches as tourism and leisure practice areas to understand their organizations and functioning. This work, based on a study of the Pertuis Charentais beaches on the French Atlantic coast, makes it possible to identify those elements which influence the filling dynamics of these spaces. This approach formalizes a model to facilitate beach management. To demonstrate the model building process, this presentation is organized into three parts. Firstly, we study beach attendance forms to understand the role of accessibility and physical constraints. Secondly, we discuss the filling process in its territoriality and its spatiotemporal dynamics. Thirdly, we study the beachgoers' preferences and their environmental perception. We show how the spatial behaviours of beachgoers are determined by residence status, practices, and environmental sensitivity. These observations are used to calibrate the filling model that is presented in its conceptual dimension.

Keywords: beach attendance, tourism and leisure practices, model building process, environmental perception.
\end{abstract}

\section{Introduction}

In a context of ever-greater coastal development of societies and growing awareness of environmental issues among administrators of the coastal space 
managers, attendance of beaches for tourism and leisure practices is often perceived as a problem generating pressure on environments.

The initial studies addressing attendance and the notion of quality on beaches were either nature studies or else focused on the question of a carrying capacity involving the determination of overcrowding thresholds. The transposition to human populations of this concept borrowed from biology and originating from the analysis of animal populations first came to the fore in the 1970 s with the Club of Rome's alarmist visions of world population growth. In the 1980s, with the Brundtland report, the idea of carrying capacity placed less emphasis on the risk of depletion of natural resources than on the importance of sustainable development. The carrying capacity was then defined as the ability of an ecosystem to maintain healthy organisms while retaining its own capacity for adaptation and renewal. In the 1990s, the United Nations Environment Programme and the World Tourism Organization developed the concept of tourism carrying capacity put forward by O'Reilly [1]. This idea is applied to different scales, of varying coherency, running from the national territory down to the local space (Butler [2]; Canestrelli and Costa [3]). Beaches have not escaped these studies aimed at determining their carrying capacity. But although the large-scale factoring in of the physico-ecological, socio-demographic and politico-economic components generally poses no problem, on local scales, this often results in an unbalanced analysis which fails to address the complex way in which these spaces function.

In parallel with these developments, an approach to quality on beaches close to management and development emerged. This development would leverage acceptance of the notion of quality. In the 1970s, the state of the environment was mainly addressed through ecological, geomorphological and landscape approaches. It was then supplemented in the 1980s by development of a normative approach which led to the establishment of regulations and labels (as in the Blue Flag, created in 1985). Quality was then defined on the basis of "objective" criteria established by scientific expert appraisals with a growing number of indicators developed in a nature-related perspective. It was not until the late 1990s that a "subjective" dimension, via the evaluation of users, was integrated into the concept of environmental quality (Duvat [4]; Leatherman [5]; Williams and Micallef [6]; Nelson et al. [7]; Vaz et al. [8]; Dwight et al. [9]). In the 1990s, there also emerged the concept of ecosystemic service in economics in order to assess the value of the environment and make it possible to quantify the cost of damage and the profitability of investments intended to preserve it. This notion popularized by the Millennium Ecosystems Assessment reports commissioned in 2000 by the United Nations defined the services provided by ecosystems contributing to human welfare. These considerations make it possible to develop the notion of environmental cultural services (spiritual, recreational, cultural, aesthetic, scientific and educational benefits, etc.).

Studies of beach territorialities and practices produced in France in the 2000s (Rieucau and Lageiste [10]; Jaurand and Luze [11]; Coëffé [12]) complemented these approaches by providing a cultural dimension. They address the qualityattendance relationship by defining spaces of practices, the notion of comfort and 


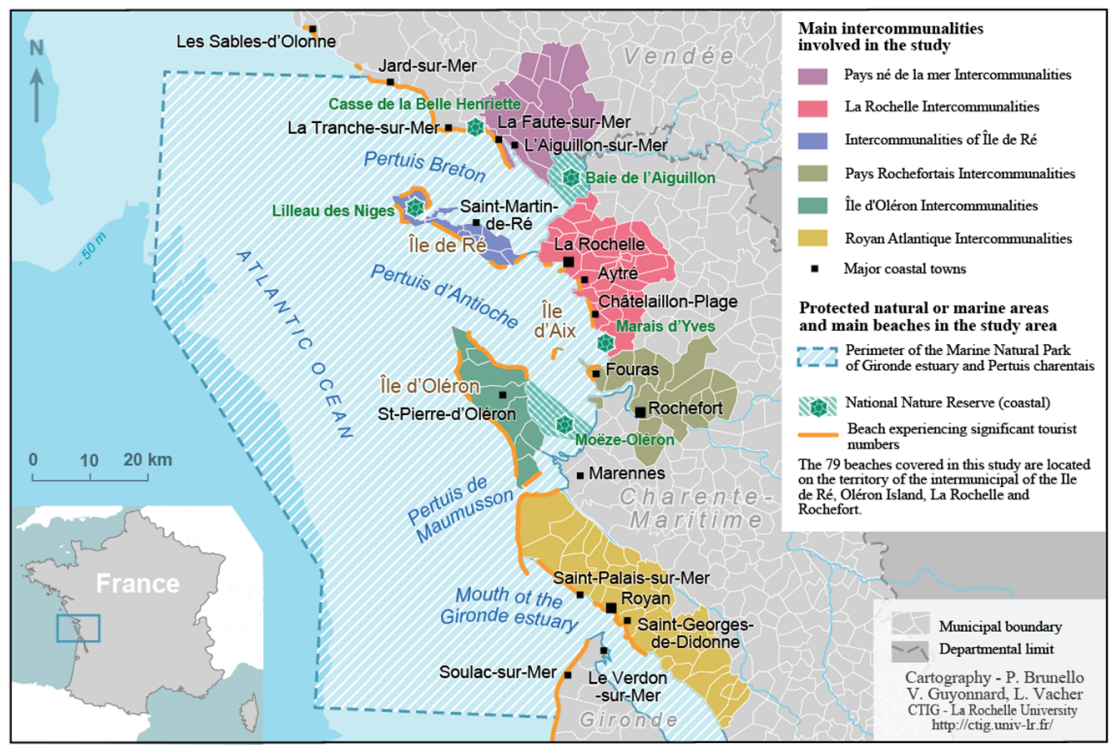

Figure 1: Pertuis Charentais beaches on the French Atlantic coast.

analysis of proxemics (Moles and Rohmer [13]; Hall [14]). They also enable analysis of the complexity of the concept of quality in the context of widely differing types of practices (relaxation, games, sports, sociability, discovery, etc.) whose spatial impacts and space consumption are extremely varied. All of these approaches serve to underscore the importance of the tourism/environment relationship and emphasize that beach attendance is very often the expression of the search for a quality environment. The construction of the notion of quality of the coastal environment (Urbain [15]; Corbin [16]) which values these spaces and justifies the cost of their maintenance and conservation, has been widely studied. The way in which this notion can evolve in line with the attendance it generates has been less so.

How does the relationship function between spaces of practices and leisure attendance whose characteristics (occupation density, changes in the image of the natural space) gradually evolve in line with filling of the places? It is in order to address this issue, which is of interest to all administrators involved in beach management and those concerned about the well-being of users, that the ASPAQUE (spatial analysis and modelling of attendance of Atlantic coast beaches in summer and its links with environmental quality) programme was able to be launched with the support of the Fondation de France.

\section{Scientific approach and methodology}

The work presented here explains how we have used a systemic approach to identify and analyse the factors involved in the dynamics of beach filling and the trends in satisfaction of those using this space for tourism and leisure practices. 
The approach developed in this programme is based on the analysis of a body of data on attendance of beaches and on the doctoral thesis of Valentin Guyonnard. The data were collected between 2008 and 2014 at 81 Pertuis Charentais beaches (fig. 1) on the French Atlantic coast. These spaces are representative of practices and attendances observable on this coastline in Western France. They offer consistency in use of the beach with practices mainly focused on bathing, relaxation and tanning (Guais et al. [17]) and cover the full diversity of situations observed on this same coastline: wild beaches, alternating with urban beaches and tourist resort beaches.

This body of data consists of beachgoer location readings generated in a Geographic Information System (GIS) for different mappings of density or distribution of beachgoers on the coast (Vacher [18]). Perception surveys were also conducted each summer on the beaches between 2008 and 2014 (1500 questionnaires per year on average) with geolocation of respondents by GPS. These readings were supplemented by counting in order to study the daily rates of beach filling.

The research approach enabling the formalization of the beach filling model as a space of practices was organized in four steps. Firstly, we endeavoured to identify the rules for the spatiotemporal distribution of attendance. Then we had to understand how the configuration of the places and the presence of attractive or repellent elements can disrupt these distributions. Finally, we addressed the issue of user perceptions and expectations which can generate different spatial behaviours. These three steps make it possible to build a beach filling model (taking into account user satisfaction) which is currently being developed within a multi-agent system (MAS).

\subsection{Analysis of beach attendance distribution}

Our first working hypothesis is that there are constants in the occupation of space which explain the regularity of attendance distribution. To understand these recurring forms it is necessary to conduct an analysis based on the observed distributions.

Processing of the density of beachgoers per grid square (20 by 20 metres) reveals that, for photographs taken in the summer, no beach in our study area (Fig. 1) attained the value of 5 sq.m available per individual was regarded as alarming (Williams and Micallef [6]) in terms of saturation (Vacher [19]). The densities which we have defined as high (still on the scale of the grid square) in the context of this work entail less than 15 sq.m of sand available per beachgoer. They are considered low at over 40 sq.m per beachgoer. On more than three quarters of observed beaches (64 beaches out of 81 ), over $50 \%$ of the beach surface area showed low or zero density. And although no high density was observed on 47 beaches, only 4 experienced high densities on 20 to $50 \%$ of their surface area. The beachgoers were therefore free to choose their location based on their expectations in terms of comfort distance.

Nevertheless, this comfort distance cannot be addressed on the scale of people. It must be processed at the level of beachgoers grouped together (cell or "participation unit" as defined by Goffman [20] who, in the absence of high 
density, are easily identifiable. Samples analysed based on observations by experts demonstrate, in the context of this programme, that over $80 \%$ of the distances between people within a cell lie between 20 and $90 \mathrm{~cm}$ (Vacher et al. [19]). On the basis of these readings, to represent the distribution of cells on the beaches, a buffer zone of $95 \mathrm{~cm}$ was applied to beachgoers on urban beaches and of $1.15 \mathrm{~m}$ for wild beaches which defines the territorial control of the cell.
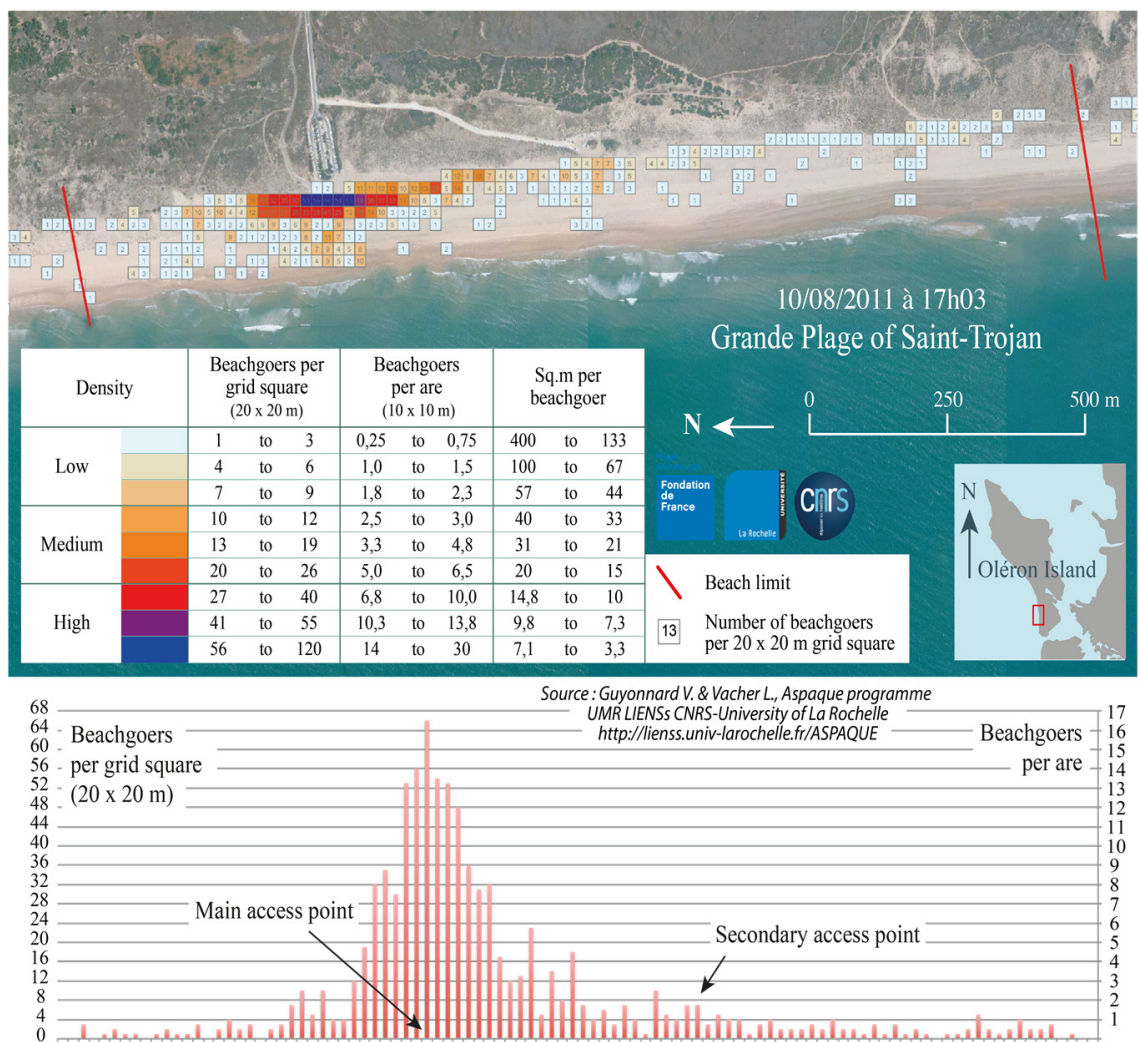

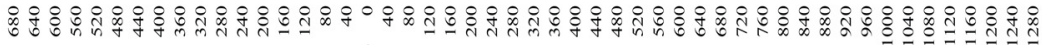

metres to the left of the main access point $\quad$ metres to the right of the main access point

Figure 2: Distribution of attendance on a beach on the Atlantic coast.

The average distances between the envelopes of a cell and of its three nearest neighbours were then calculated for the entire population. The regularity of the spacing between cells can thus be approximated. For an urban beach, the value of this distance is below $2.5 \mathrm{~m}$ for more than $90 \%$ of cells, while on a wild beach values are more spread out and almost always vary between $1 \mathrm{~m}$ and $5 \mathrm{~m}$ (Vacher et al. [19]). The regularity of these values illustrates the regularity of 
distributions on urban beaches and density gradients which are generally characteristic of more isolated beaches.

These filling gradients are particularly visible for the more isolated beaches where a single access point controls filling of the beach (Fig. 2). We can then see that the highest concentrations are reached between 20 and $40 \mathrm{~m}$ from the access point before declining slowly at first, then more markedly beyond $80 \mathrm{~m}$. At $200 \mathrm{~m}$ from the access point, attendance becomes discontinuous. In the event of high attendance, it is towards $300 \mathrm{~m}$ that attendance becomes marginal. However, as at the Grande Plage of Saint-Trojan on the Île d'Oléron (Fig. 2), it is often difficult to measure the proportion of beachgoers walking some distance from the central access point and that of those arriving by a secondary access point. These values are consistent with what is observed in other contexts (Pereira da Silva [21]) even if the limited number of studies and different methodologies make it difficult to generalize.

\subsection{Disturbances and dynamic character of spatial distribution}

The constants of beach attendance distribution organize space into a scattering of cells laid out in a regular pattern on urban beaches or in the form of a gradient on large wild beaches. This lay-out, however, may be disrupted by attractive or repulsive elements on the beach and by the dynamic nature of filling.

The beach is, in fact, a space of practices which follows a filling rate in several phases during a given day. On the beaches in our study space, filling occurs in two stages when the weather conditions are stable. Firstly, filling in late morning giving rise to an initial peak of varying intensity towards 12 noon, then a marked recommencement between $2 \mathrm{pm}$ and $3 \mathrm{pm}$ before peak attendance is attained at around $4.30 \mathrm{pm}-5 \mathrm{pm}$. Attendance in the morning, which can vary depending on the tide, will reach between 25 and $60 \%$ of the volume recorded during the peak attendance in the afternoon. The positioning of people during this process was analysed for 3 beaches from photographs taken from the top of a post every 15 minutes between $10 \mathrm{am}$ and $7 \mathrm{pm}$ in July 2014 . These readings show that filling was initially irregular and uniform from the access point. This type of occupation could last until late morning. In the afternoon, a densification of this attendance was observed with new arrivals taking positions in the interstitial spaces and the appearance of a density gradient from the heart of the beach. From $5 \mathrm{pm}$, occupation of the beach became increasingly irregular with the departure of beachgoers although the spread remained extensive.

To calibrate the beach filling model, we analysed the repulsive or attractive nature of different elements based on the observation of aerial photographs. The distribution of beachgoers mainly depends on distance to the access point, but it can also be sensitive to the presence of a supervised bathing area which tends to focus attendance. This attractive aspect is undeniable, even if it does not apply to all populations as we will see with the presentation of expectations. The presence of a repulsive space is often related to the presence of seaweed, pebbles or seashells in compact banks on the beach. This element is currently emerging as an important factor in the management of non-urban beaches with environmental awareness. In fact, the conventional mechanical cleaning still practiced today on 
urban beaches is increasingly considered inappropriate on "natural" beaches. The presence of natural waste associated with the tide is therefore becoming a standard feature on the Atlantic coast in the tourist season and giving rise to strategies aimed at avoiding those areas of the beaches concerned. Beach towels are laid down in areas separate from zones covered with oyster shells or seaweed.

\subsection{Factoring in user perceptions and expectations}

The formalization of the filling model requires analysis, in addition to constants in terms of occupation of the space, of user expectations depending on the parameters affecting their spatial strategies. In fact, the model is used in contexts of different attendances and must be able to take account of attendance of which, for example, the age, the level of local attendance and the proportion of people using the beach for sociability practices, may be variable. Similarly, the model can take account of the consequences of an environmental awareness action which influences the negative perception of the presence of seaweed on the beach. Identification of discriminant parameters as part of the process occurs in three directions.

Firstly, spatial behaviours are largely influenced by the age of beachgoers and the presence of children in the cells. Families with children are clearly attracted by the supervised bathing area when such exists and by the water's edge where it is easy to supervise children. We should point out that bathing is rarely as dangerous in our study area as it is on the southern beaches of the French Atlantic coast. The cells of teenagers, in what may appear to be a strategy to avoid younger children, are overrepresented in the upper beach area. It may also be a reason why childless groups are as likely to avoid the proximity of supervised bathing areas as to seek it. We can also see that the higher the numbers of beachgoers making up the cell, the more this cell will tend to choose a position immediately on entering the beach.

A second element affecting the choice of location is the status of people in the place. Tourists, secondary residents, local residents or day trippers do not have the same expectations and the same perceptions of the beach environment. Our surveys, coupled with GPS positioning, demonstrate, for instance, that secondary residents are much more mobile than principal residents. The fact that local residents choose positions closer to access points than others is related to regular use of the beach, while tourists and secondary residents are in an exceptional relationship with the coastal environment.

We might also add that the local residents who frequent the beach in summer are among those who are able to adapt to these summer attendances and that the others, in a process of self-regulation, are absent from this space on a seasonal basis (De Ruyck et al. [22]). The fact that the secondary residents are the most attracted to the least densely populated areas of the beach can also be linked to the environmental sensitivity of this population which is greater than for other people on this Charente coastline.

The expectations are the final parameter which comes into play in understanding spatial strategies. Those people attending Pertuis Charentais 


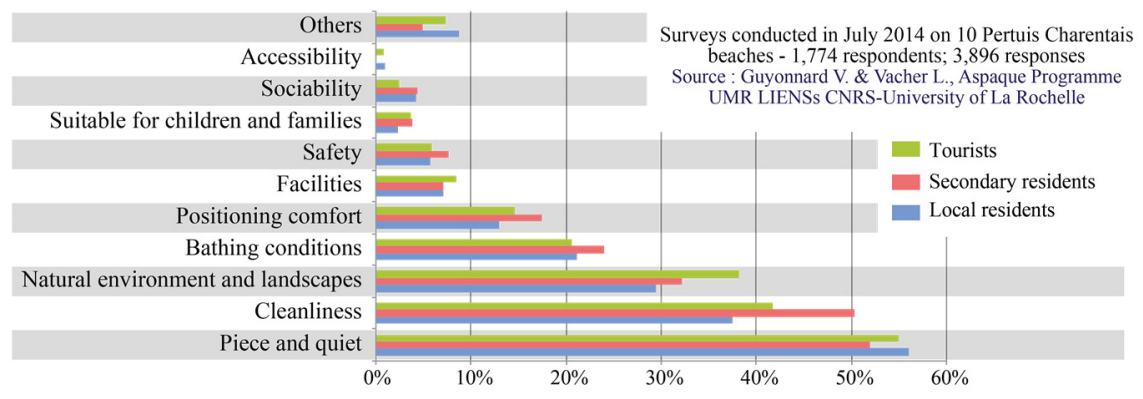

Figure 3: Principal types of expectations on Charente beaches in July 2014.

beaches are not particularly original in terms of what can be observed on other European or American beaches (Botero et al. [23]; Roca and Villares [24]; Marin et al. [25]). The peace and quiet are cited by more than half of beachgoers as well as the notion of "comfortable positioning" (fig. 3) which demonstrate attention to the space around them. Bathing conditions are more readily identified than safety, which demonstrates a low correlation between the two and reinforces the idea of a safe Charente coastline for families. The second high expectation concerns the subjective notion of "cleanliness". This is important on the Charente coastline where "poor cleanliness", although it is commonly associated with the presence of cigarette butts in the sand, is also classically associated with the presence of natural elements in the environment (pebbles, mud, seashells, seaweed, jellyfish). The survey shows that people with high environmental sensitivity (mostly measured in this work through knowledge of the coastal flora and fauna) are less put off by these natural "pollutions" and tend to choose a position further from the access point than others.

\section{Proposed model and discussion}

The approach developed through this programme therefore makes it possible to formalize a computer model simulating filling of the beach which we present here in its conceptual dimension (fig. 4). We will explain its structuration and parameterization before concluding on its value as a decision-support tool for the management of coastal zones.

As part of this modelling approach, the beach is considered as a space of tourism and leisure practices. In addition, its structuration is organized around two main inputs: a "positioning space" input and a "user cell" dimension.

The "positioning space" input concerns the support surface of the model which can be configured as an open space (wild beach type) or as a closed and bounded space (urban beach type). Its extension bordering the sea, its depth and the number of its access points can all be defined. The nature of the sand can be considered as uniform, or as comprising areas where the density of seashells, pebbles or seaweed delimits positioning sectors which are secondary or even impossible. These disruptive elements may, particularly in the case of seaweed, 


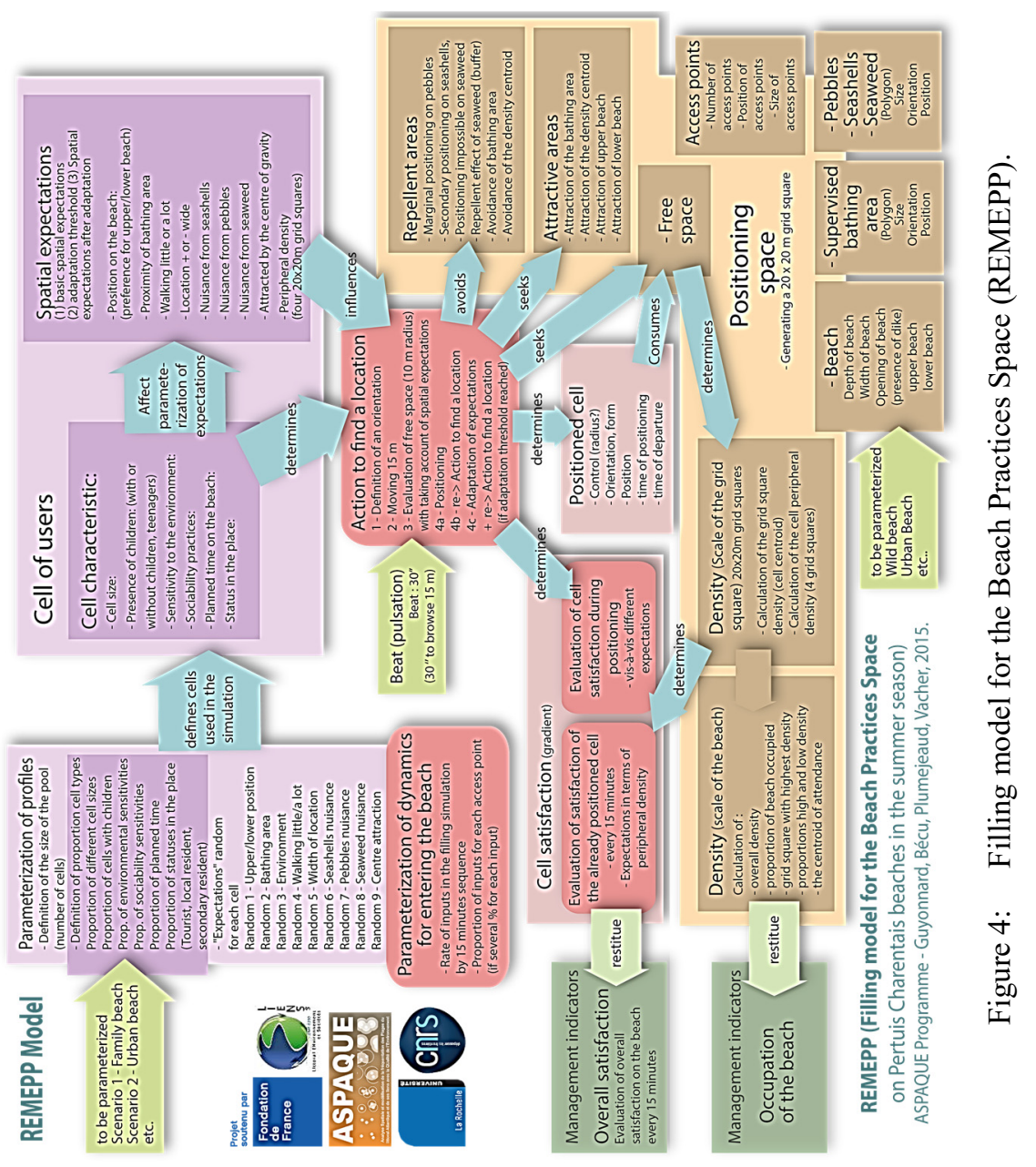


generate a "buffer zone" around themselves where positioning will often be avoided. Conversely, a supervised bathing area can be placed on the beach generating a halo of attractiveness for certain categories of users. Since this model is a beachgoers' positioning model, the intertidal zone, which may be significant in the region studied, is not taken into account. In fact, since the sand remains wet between two tides this is not where beachgoers normally lay down their towels. A last characteristic of the support space has a dynamic character and is the centre of gravity for attendance on the beach. This centroid may have an attractive or repulsive aspect depending on the type of user practices (sociability, relaxation) and will be permanently recalculated according to filling of the beach.

The "cell" input concerns units who position themselves on the beach. These cells of users exhibit characteristics affecting behavioural indicators in the choice of the positioning space. For each indicator, the variables have been set according to the analyses and surveys carried out during the first part of the programme. These variables concern: the cell size (affecting the control of the cell and mobility); the presence of children (affecting the attraction of the water's edge and the bathing area); the teenager cell (affecting location in the upper beach area and an attraction for density); environmental sensitivity (affecting tolerance of natural waste on beaches and the ability to move away from the access point to find lower occupancy densities); status as tourist, secondary resident or principal resident (affecting the propensity to move away from access points).

Before running a simulation of the filling of a beach, it is necessary to define in the model the proportion of different profiles entering the beach by the access point(s) and the rate at which these cells enter the beach. Once the simulation is launched in a computer application, filling takes place on the scale of the beach while making continual changes to configuration of the space density.

At the level of the cell, two dynamic dimensions are observed. The first corresponds to the positioning process conditioned by expectations in terms of comfort defined in the profiles. On entering the beach, the space is examined by the cell to see if conditions corresponding to the expectations of their profile are available in a $10 \mathrm{~m}$ radius around it. If this is the case, the cell moves into the available space, if not it will move $15 \mathrm{~m}$ away from the access point and conduct a fresh analysis and so on until it finds a space corresponding to these comfort criteria. If it fails to find one, the cell may reduce its demands. Its level of satisfaction will then decline as of positioning.

Satisfaction is, in fact, the second dynamic dimension at the cell level. It may decline if finding a location takes a long time. But this dynamic dimension can also manifest itself for positioned beachgoers. If density conditions change around the cell, the level of satisfaction may decrease (or increase). This satisfaction dimension is, of course, essential in the model. It enables measurements at the level of each cell but, in particular, also makes it possible to obtain an indication of the overall level of satisfaction of beach users. 


\section{Conclusions and prospects}

The main result of this paper concerns a method for the definition of a beach filling model for the French Atlantic coast in summer. This model is founded on the characterization of behaviours and positions in the beach space defined based on observations of actual distribution and surveys aimed at understanding the expectations of beachgoers. It simulates filling of the beach while taking into account a profile dimension for groups of beachgoers arriving on the beach together (cell) and a characterization dimension of the beach support with definition of attractive or repulsive areas. It makes it possible to assess individual and overall satisfaction on the beach during this filling process.

This model, whose computer implementation is in progress, is now being made available to the scientific community after having been the subject of consultations with administrators managing beaches in ten or so territories (municipalities or intermunicipalities) responsible for around forty beaches in the Pertuis Charentais region. These consultations highlighted the value of the model in defining solutions for combining the quest for satisfaction by beach users and the objective of sustainable and responsible management of coastal environments. Following initial contacts with the administrators, two dimensions require further investigation: the question of the definition of the multifaceted notion of cleanliness and that of the impact of set-up of temporary special events (advertising, sports, music) on beaches for which local authorities are regularly contacted, particularly on urban beaches and beaches in tourist resorts.

\section{References}

[1] O’Reilly, A.M., Tourism carrying capacity. Tourism Management, 7(4), pp. 254-258, 1986.

[2] Butler, R.W., The Concept of Carrying Capacity for Tourism Destinations: Dead or Merely Buried? Progress in tourism and hospitality research, 2(3-4), pp. 283-294, 1996.

[3] Canestrelli, E. \& Costa, P., Tourism carrying capacity: A fuzzy approach. Annals of Tourism Research, 18(2), pp. 295-311, 1991.

[4] Duvat, V., Interest of quality-based policies for Integrated Coastal Zone Management implementation: Lessons learnt from a French case study. Ocean \& Coastal Management, 54(11), pp. 831-843, 2011.

[5] Leatherman, S.P., Beach Rating: A Methodological approach. Journal of Coastal Research, 13(1), pp. 253-258. 1997

[6] Williams, A. \& Micallef, A., Beach Management-Principles \& Practice. Earthscan: London, 2009.

[7] Nelson, C. et al., Beach awards and management. Ocean \& Coastal Management, 43(1), pp. 87-98, 2000.

[8] Vaz, B. et al., The importance of user's perception for beach management, Journal of Coastal Research, Special Issue 56, pp. 1164-1168, 2009. 
[9] Dwight, R.H. et al., Beach attendance and bathing rates for Southern California beaches. Ocean \& Coastal Management, 50(10), pp. 847-858, 2007.

[10] Rieucau, J. \& Lageiste, J., La plage, un territoire singulier: entre hétérotopie et antimonde. Géographie et cultures, 67, pp. 3-6, 2008.

[11] Jaurand, E. \& Luze, H. de, Ces plages où les genres s'affichent? Les territoires du nu sur la Côte d'Azur. Le genre des territoires: masculin, féminin, neutre, ed. C. Bard, Presses de l'Université d'Angers: Angers, pp. 227-240, 2004.

[12] Coëffé, V., La plage, fabrique d'une touristi(cité) idéale. L'information géographique, 74(3), pp. 51-68, 2010.

[13] Moles, A. \& Rohmer, E., Psychologie de l'espace, Casterman: Paris, 1972.

[14] Hall, E.T., La dimension cachée, Seuil: Paris, 1971.

[15] Urbain, J.-D., Sur la plage, Payot: Paris, 1994.

[16] Corbin, A., Le territoire du vide. L'Occident et le désir du rivage 17501840 Flammarion: Paris, 1988.

[17] Guais, A., Vacher, L. \& Vye, D., Fréquentation des plages de CharenteMaritime, Rapport Campagne d'enquêtes été 2010, UMR 7266 LIENSs CNRS - Université de La Rochelle, 2011.

[18] Vacher, L., Réflexion géographique sur la distance, une approche par les pratiques de tourisme, Mémoire d'HDR, Université d'Angers: Angers, 2014.

[19] Vacher, L. et al., Atlas de la fréquentation des plages de CharenteMaritime, Campagne 2014, Observatoire des Pratiques de Tourisme et de Loisir-ECOP, UMR 7266 LIENSs CNRS - Université de La Rochelle, 2015.

[20] Goffman, E., La mise sen scène de la vie quotidienne. Tome 2 Les relations en public, Les Éditions de Minuit: Paris, 1973.

[21] Pereira da Silva, C., Beach Carrying Capacity Assessment: How important is it? Journal of Coastal Research, 36, pp. 190-197, 2002.

[22] De Ruyck, M.C., Soares, A.G. \& Mclachlan, A., Social Carrying Capacity as a Management Tool for Sandy Beaches. Journal of Coastal Research, 13(3), pp. 822-830, 1997.

[23] Botero, C. et al., Reasons for beach choice: European and Caribbean perspectives. Journal of Coastal Research, (65), pp. 880-885, 2013.

[24] Roca, E. \& Villares, M., Public perceptions for evaluating beach quality in urban and semi-natural environments. Ocean \& Coastal Management, 51(4), pp. 314-329, 2008.

[25] Marin, V. et al., Users' perception analysis for sustainable beach management in Italy. Ocean \& Coastal Management, 52(5), pp. 268-277, 2009. 